\title{
DEGRADED LATERITIC SOILS CAPE AND LAND USES IN BIRBHUM DISTRICT, WEST BEN- GAL, INDIA
}

\section{Degradeção dos solos lateríticos do Cabo e utilização dos solos no Distrito de Birbhum, Bengala Oci- dental, Índia}

V. C. Jha

Professor and Head, Department of Geography Visva-Bharati University, Santiniketan-731235

West Bengal - India

vcjha@asia.com

S. Kapat

Project Scientist, Department of Geography Visva-Bharati University, Santiniketan West Bengal - India

Artigo recebido para publicação em 04/05/2011, e aceito para publicação em 12/09/2011.

\begin{abstract}
Degradation of lateritic environment as found in the south western and eastern Birbhum district can be considered as irresistible. Inherently poor physical and chemical status of existing lateritic soil profile and radical conversion of land uses as observed at cadastral level are the key factors of land degradation. Lateritic soilscapes are mostly affected by water erosion induced, vegetal and anthropogenic degradation attaining severe and very severe degradation status. Degraded lands in sample mouzas like Ballabhpur, Shyambati, Chawpahari Jungle, Bodakuri and Pachami account for 60.33\%, 71.42\%, 72.99\%, 87.31\% and $79.66 \%$ respectively out of their total lateritic exposures. In other words about 36.98\%, 71.42\%, $61.73 \%, 56.70 \%$ and $76.02 \%$ out of their total village areas and mostly non agricultural land use are affected by it. Four degraded villages get the higher priority for friendly landscape conservation actions.
\end{abstract}

Keywords: Degraded Lateritic Soilscape. Land Use. Physical and Chemical Properties of Soils. Lateritic Terrain. Birbhum District.

RESUMO: $\quad$ A degradação do ambiente laterítico como aquele encontrado no sudoeste e leste do distrito de Birbhum pode ser considerado como irreversivel. A fragilidade física e química inerente aos solos lateriticos e a radical transformação nos usos da terra, observados a nível cadastral, são os principais fatores de degradação da terra. As paisagens lateríticas são as mais afetadas pela água da erosão induzida, seja pela degração da vegetação, pela ação antrópica, gerando elevados status de degradação do solo. Em níveis amostrais a degradação da terra é alta como nas parcelas em Ballabhpur, Shyambati, Jungle Chawpahari, Bodakuri e Pachami com valores de 60,33\%, 71,42\%, 72,99\%, 87,31\% e 79,66\%, respectivamente para o total de solos lateriticos expostos. Em outras palavras chegam a atingir 36,98\%, $71,42 \%, 61,73 \%, 56,70 \%$ e 76,02\% quando comparados com o total de área das aldeias. Quatro aldeias com áreas degradadas devem receber maior prioridade para ações de conservação da paisagem.

Palavras-chave: Paisagem lateritica degradada, uso da terra, propriedades físicas e químicas do solo, terrenos lateríticos. Distrito de Birbhum 


\section{INTRODUCTION}

Land degradation has greater impact on food security, rural livelihood and environmental regulatory capability as noted in many developing country like India. Its impact on soil comes so creepingly that land users hardly contemplate initiating ameliorative or counter balance measures (BRAIMOH et al. 2008). Moreover, climatic changes on soil bring about changes in rate of erosion, resilience, sensitivity and susceptibility to stress and potential reversibility of damage. Today's rapid population growth and globalization are responsible for this situation. Globalizing economy give rises new more challenges to the sustainable use of land by land use change, more expectations from fragile landscape and markets at local national and international levels.

So at the edge of Malthusian precipice regarding adverse man land ratio, it is true if all resources are harnessed to minimize soil degradation, sufficient food will feed the population. But vantage slogan-think globally and act locally hangs its success.

India also confronts such critical landscape ecology because of its growing population (1.15 billion people, $17 \%$ of world population) and degraded land of $105.48 \mathrm{mha}$ (32.07\% of the total geographical area TGA of the country). Land degradation processes are water erosion (26.21 mha or $10.21 \%$ of TGA), eolian $(17.77 \mathrm{mha}$ or $5.34 \%)$ and vegetal $(17.63 \mathrm{mha}$ or9.63\%), frost (3.1\%), salinity and alkalinity (1.6\%), mass movement $(1.35 \%)$, water logging $(0.3 \%)$, rocky /barren $(0.5 \%)$ and others $(0.04 \%)$ as estimated by Ajai et al. (2009).

In lateritic environment, land degradation is acute because of aberrant weather, drought, crusting, acidity, water erosion, mass wasting, water-logging, NKP deficiency, low water holding capacity and wide range of land use conversion .

Since the time of Buchanan (1807), there are worldwide studies on laletrites as noted in the following works regarding concepts on the origin of Indian laterites by Roychowdhury et al. in 1965 Genesis of barren laterite by Thomas in 1981, Iron constituent of the latosolic soil in Brazil by Volkoff in 1982, Geomorphological analysis of laterites and its role in prospecting by Mcfarlane in 1986, -Denudation processes and landform characteristics in lateritic region of Birbhum district by Jha in 2005 -Laterites and lateritoids of Rahr Bengal by Biswas in 1987, -Basic researches on laterites in the tropical countries by Banerjee in 1998, -Red and laterite soil management by Sehgal et al. in 1998, -The early history of the use of term laterite by Prescott in 2006, -Investigations of lateritic stones for building purposes in Malabar region by Santhanam et al. (2008), - High Deccan Duricrust in India by Cliff and Hetu in 2008. Rill and gully erosion risk of lateritic terrain in Birbhum district, West Bengal, India by Jha and Kapat in 2009 and other. Beside these, more researches on land degradation in relation to geomorphic processes, change in land uses, economic development and globalization have been conducted as done Sing and Dubey (2002), Valentin (2005), Zhang et al. (2008), Pacardo (1984), Grau et al.(2008), and others.

In fact, policies exist to combat degradation problem. But these have not been properly enforced. Often development is done at the cost of environment and its quality. So multidisciplinary holistic approaches for monitoring and combating land degradation processes are desirable with thrusts towards understanding of: precise nature and impact of degradation process; acceptable amount of soil loss; benefit and cost analysis of soil conservation measures; advance knowledge on more technical of soil erosion management; social and economic dimensions which seems to be most problematic in soil erosion management and participation and responses of communities.

The present study has the following attempts: the characterization of lateritic soil profile in terms of their morphology and physico-chemical properties at different sites of land degradation; assessment of degraded land cover/uses with their extents, severity with pedo-geomorphic constraints in lateritic environment and priority based action plan at village level.

\section{DATABASE AND METHODOLOGY:}

Present study is actually field work intensive integrated study. Five sample villages have been chosen considering extent of lateritic exposures and degraded land cover/uses under varying relief deformation and average annual soil loss, forest blank and 
quarrying of lateritic waste or rock. Toposheets and precision of geocoded IRS, P6 and LISS III December $2006-73 \mathrm{M} / 5,73 \mathrm{M} / 10$ and $72 \mathrm{P} / 12$ on scale of $1: 50,000$ and cadastral maps on scale of $1 "=16$ miles and field data on extent and type of degraded land use are used for preparing inventories and mapping degraded land uses under different pedo geomorphic characteristics. Five soil profiles of degraded sites have been studied in different sample villages. Horizons have been differentiated on the basis of colour (moist), texture, structure and iron concretion. Soil samples from different horizons of lateritic profiles have been collected for laboratory analysis relating to particle size, $\mathrm{pH}$, organic carbon and base saturation. Universal soil loss equation (Wischmeir; Smith 1978) has been applied ( $\mathrm{A}=\mathrm{RKLSCP}$ where A-Average annual soil loss, R-Rainfall erosivity, K-Soil erodibility, LS-
-Slope and topography and CP-Existing cropping and conservation practices) to derive annual top soil loss on the basis of Fournier index (ratio between mean annual rainfall and highest mean monthly rainfall), particle size of lateritic samples, guideline of central soil conservation and training institute for value of $\mathrm{CP}$ factor, Dehradun 2001 toposheets, cadastral map ,field data and others. Scaling and weighting to determine degradation status of sample villages have been done according to the relative importance of variables.

\section{Study-area:}

The study area (23 36'N-24' 4'40 N", $\left.87^{\circ} 25^{\prime} 30^{\prime \prime} \mathrm{E}-87^{\circ} 39^{\prime} 26^{\prime \prime} \mathrm{E}\right)$ lies between the western upland and the eastern alluvium plain (Figure 1).

Figure 1: Location of Birbhum District, West Bengal, India

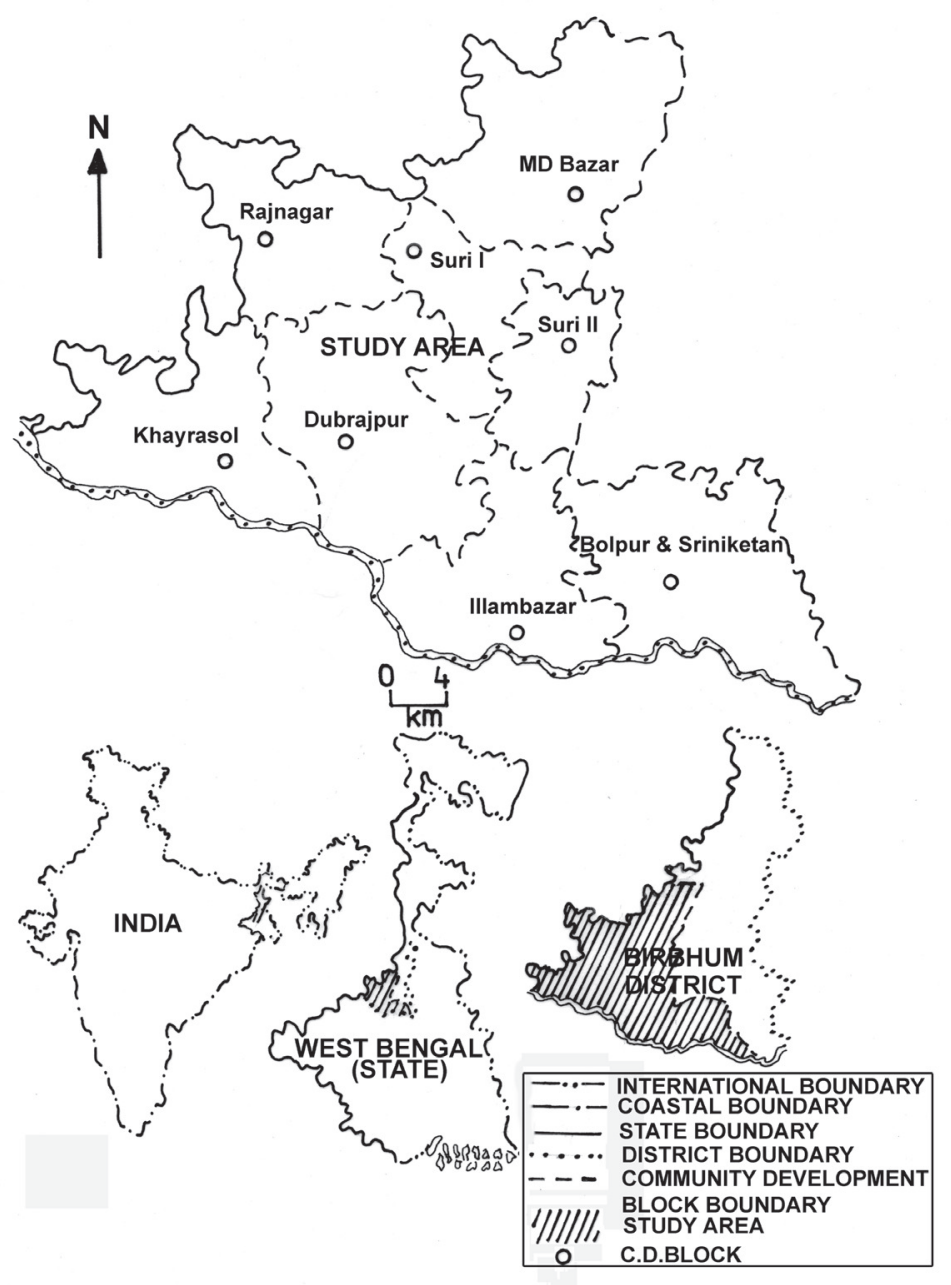


It belongs to the Rahr region also known as the Self of lateritic alluvium. Five sample Mouzas are Ballabhpur and Shyambati in Bolpur-Sriniketan C. D. Block, Chawpahari Jungle in Illambazar C. D. Block, Bodakuri in Dubrajpur C. D. Block and Pachami in Mahammad Bazar C. D. Block. The study area having significant extent of laterites confront land degradation problem.

\section{RESULT AND ANALYSIS:}

\section{Physical and chemical charateristics of degraded lateritic soil profiles:}

It is observed that the lateritic soil profiles as developed under prolong leaching (Figures 2 and 3) are typically suffering from constraints of acidity, plenty of sesquioxides, low base saturation, deficiency of organic matters and water erosion (Figures 2 and 3). Profiles have varying ranges of brown colours. Texture in A horizon and the upper B horizon is coarse in nature ranging between loamy sand to sandy loam with contents of sand between $61.19 \%$ and $85.7 \%$, silt less than $10 \%$ and clay less than $10.0 \%$. The lower B horizons consists of plenty of iron concretion (diameter of $1 \mathrm{~mm}-10 \mathrm{~mm}$ particularly at the depth of $40 \mathrm{~cm}-90 \mathrm{~cm}$ ) and clay more than $30 \%$ indicating illuviation of clay. Structure ranges from Granular to apedal at the surface and in the upper B horizons; structureless to sub angular in B22t and massive in the lower B horizon. Consistency is friable when it is moist. Soils ranges from acidic to strongly acidic as evidenced by PH values between 4.12 - 5.2. But the profile at Pachami depicts quite different $\mathrm{pH}$ values between 5.7 and 7.6. Very low magnitude of electrical conductivity $\mathrm{mmhos} / \mathrm{cm}$ indicates no problem of salinity. Base saturation is mostly less than $40.0 \%$. But it is more than $40.0 \%$ in Ballabhpur mouza probably because of existence of wet land and the South Kopai Main canal. They are deficient in organic matters $(0.01 \%-0.3 \%)$. Common morphological forms of laterites are nodular, pisolitic, massive and concretionary as found in sample profiles in sample villages. Pebble and pisolitic gravel assorted layer resting on massive is distinctly found in well matured gullied terrain under Ballabhpur reserve forest. Massive laterites with thin pisolites forming surface of gently sloping lateritic landscape are well marked in Shyambati Bodakuri and Pachami villages. Nodular laterites are very common in the study area. Hence lateritic soilscape is inherently susceptible to degradation as reflected in their physical and chemical status of sample lateritic profiles.

Figure 2: Physical and Chemical Properties of Different horizons of samplelateritic profiles.

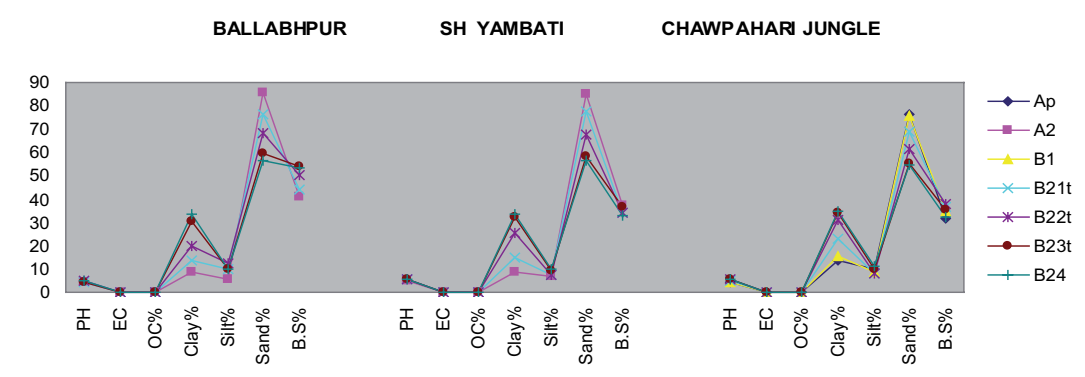

Figure 3: Physical and Chemical Properties of Different horizons of sample lateritic profiles.

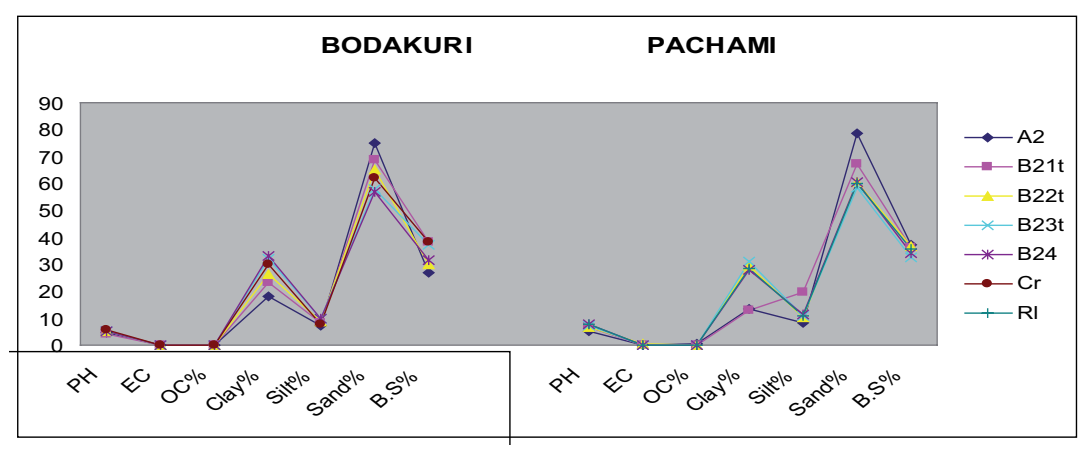

Soc. \& Nat., Uberlândia, ano 23 n. 3, 545-558, set/dez. 2011 
Figures 4, 5, 6, 7, 8, 9, 11 and Table 3 and 4 reveal the following pedo-geomorphic characterisics of degraded lateritic landscape in terms of degraded land cover and uses:

- Ballabhpur mouza (Bolpur-Sriniketan block), $60.31 \%$ out of its total lateritic exposure $\left(61.30 \%\right.$ or $\left.3.58 \mathrm{Km}^{2}\right)$ is degraded as manifested in degraded agricultural land (7.26\%), highly deformed rill gully induced forested badland (23.74\%), scrubland $(2.79 \%)$, degraded reserve forest $(5.30 \%)$, rill and sheet erosion induced barren terrain with less relief deformity $(7.82 \%)$ and badland with settlement $(6.70 \%)$.

- Shyambati mouza (Bolpur-Sriniketan C. D. block) has undergone remarkable conversion

Figure 4: Degraded Land Cover/Uses Inlateritic Environment Mouza: Shyambati, C.D.Block: Bolpur-Sriniketan of its widely deformed lateritic badland into built up area $\left(0.20 \mathrm{~km}^{2}\right.$ or $17.85 \%$ out of laterite soilscape) $.71 .42 \%$ of this mouza is still showing degrading landscape ecology as enhanced by inherent poor chemical and physical status of erodible laterites and urban sprawling.

- Chawpahari Jungle Mouza in Illambazar C D block has forest dominated largest lateritic exposure covering $14.70 \mathrm{~km}^{2}$ or $84.57 \%$ out of the total village area.72.99\% of the lateritic enclosure or $61.73 \%$ of village area are degraded. Widespread rill- gullied terrain (65.03\% of its exposure) proves its higher water induced erodibility (Figure 10).

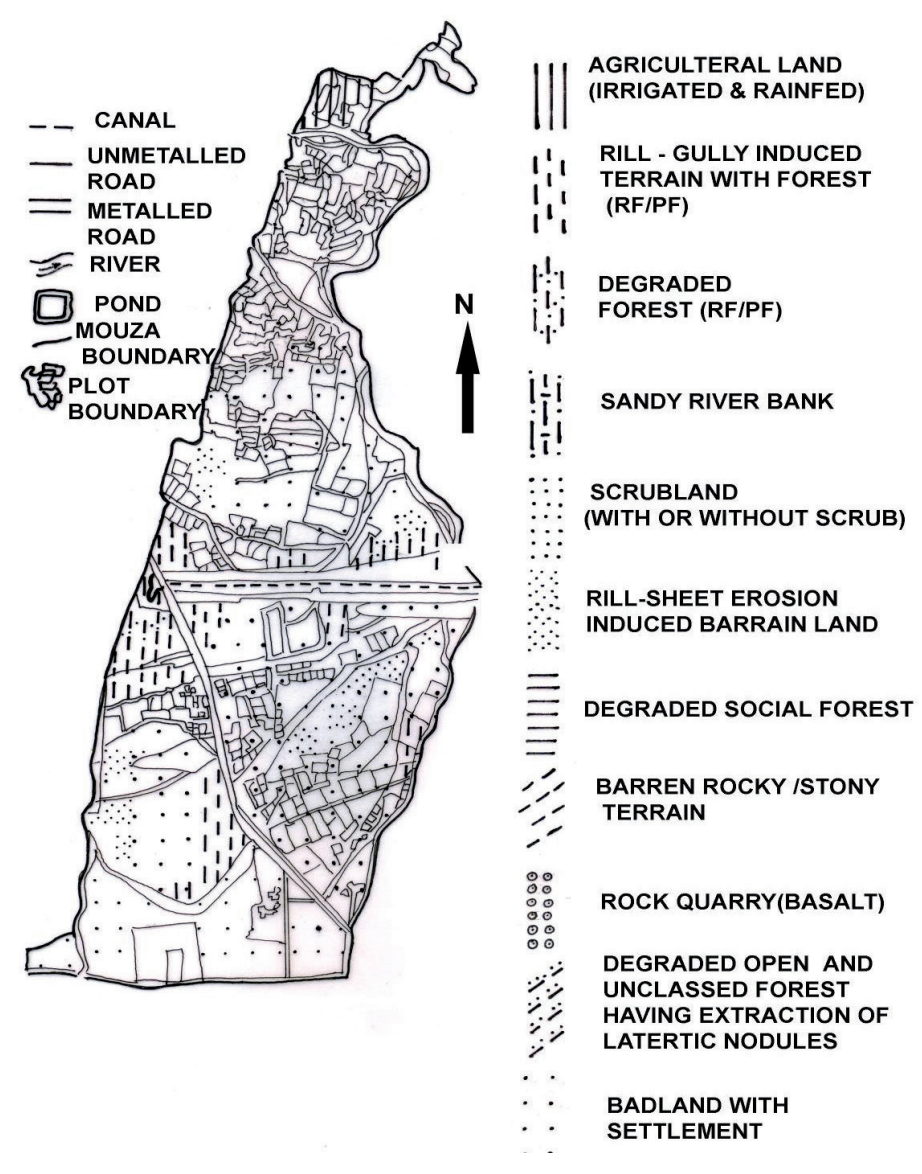

Soc. \& Nat., Uberlândia, ano 23 n. 3, 545-558, set/dez. 2011 
Figure 5: Degraded Land Cover/Uses Mouza: Ballavpur C.D.Block: Bolpur \& Sriniketan

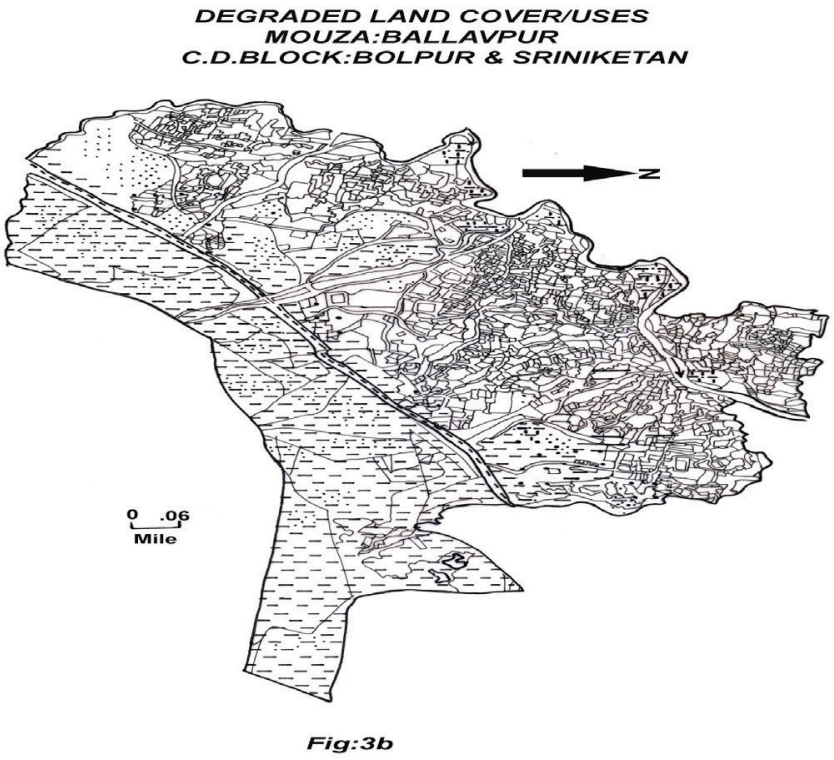

Figure 6: Degraded Land Cover/Uses Mouza: Chapahari Jungle C.D.Block: Illambazar

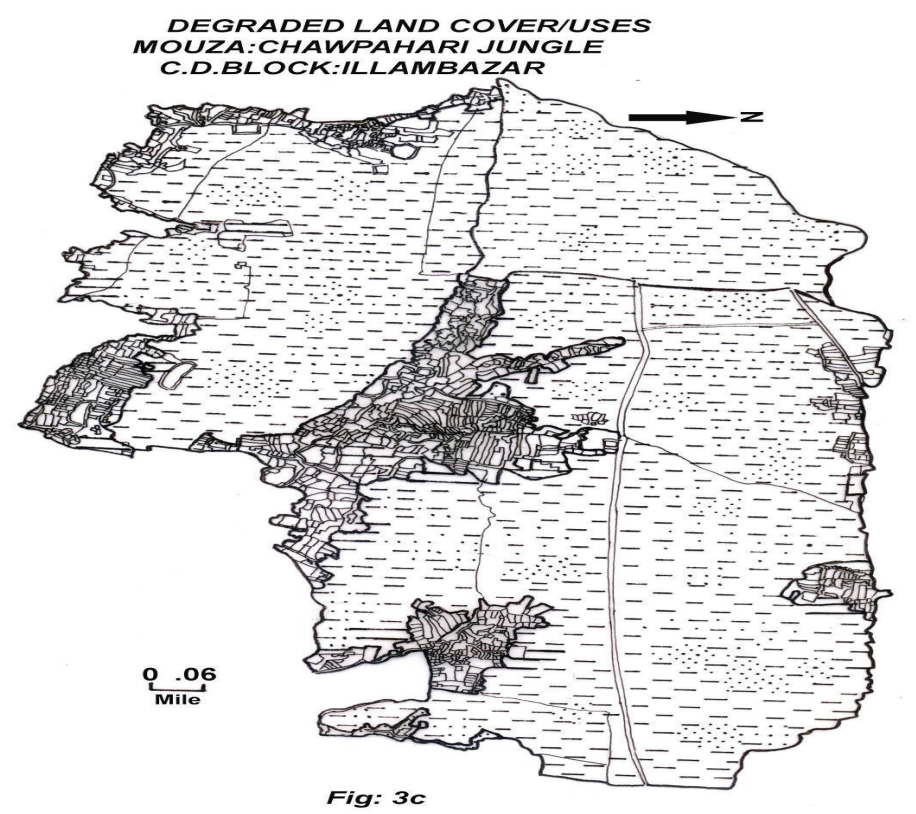

Soc. \& Nat., Uberlândia, ano 23 n. 3, 545-558, set/dez. 2011 
Degradação das paisagens de solos lateríticos e uso da terra no distrito de Birbhum, Bengala Ocidental, Índia V. C. Jha, S. Kapat

Figure 7: Degraded Land Cover/Uses. Mouza: bodakuri - C.D.Block: Dubrajpur

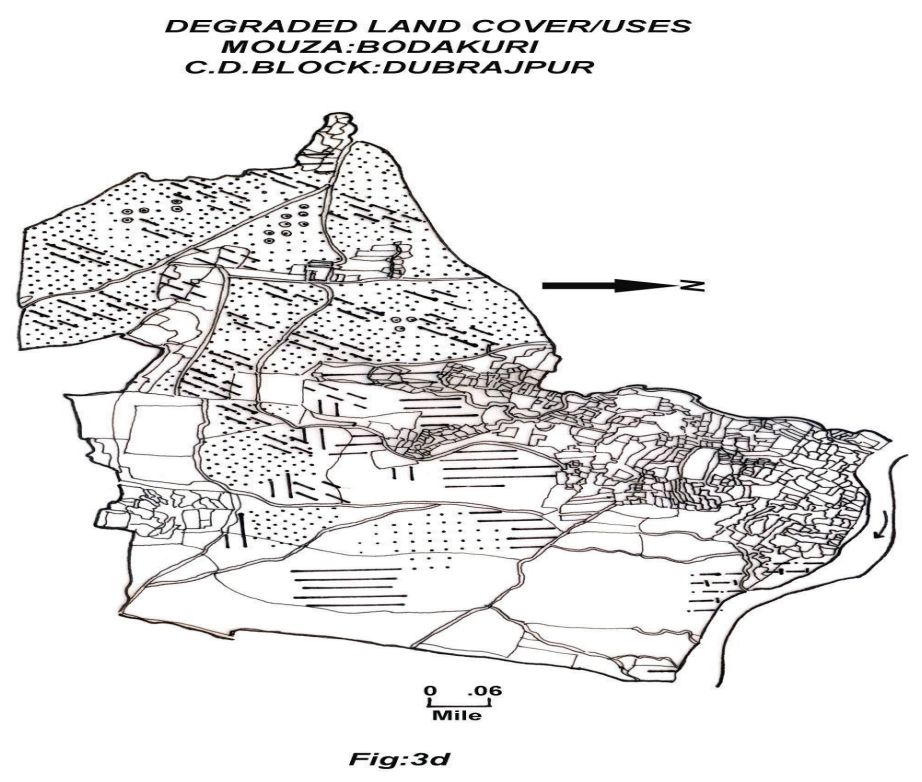

Figure 8: Degraded Land Cover/Uses. Mouza: pachami. C.d. Block: md bazar

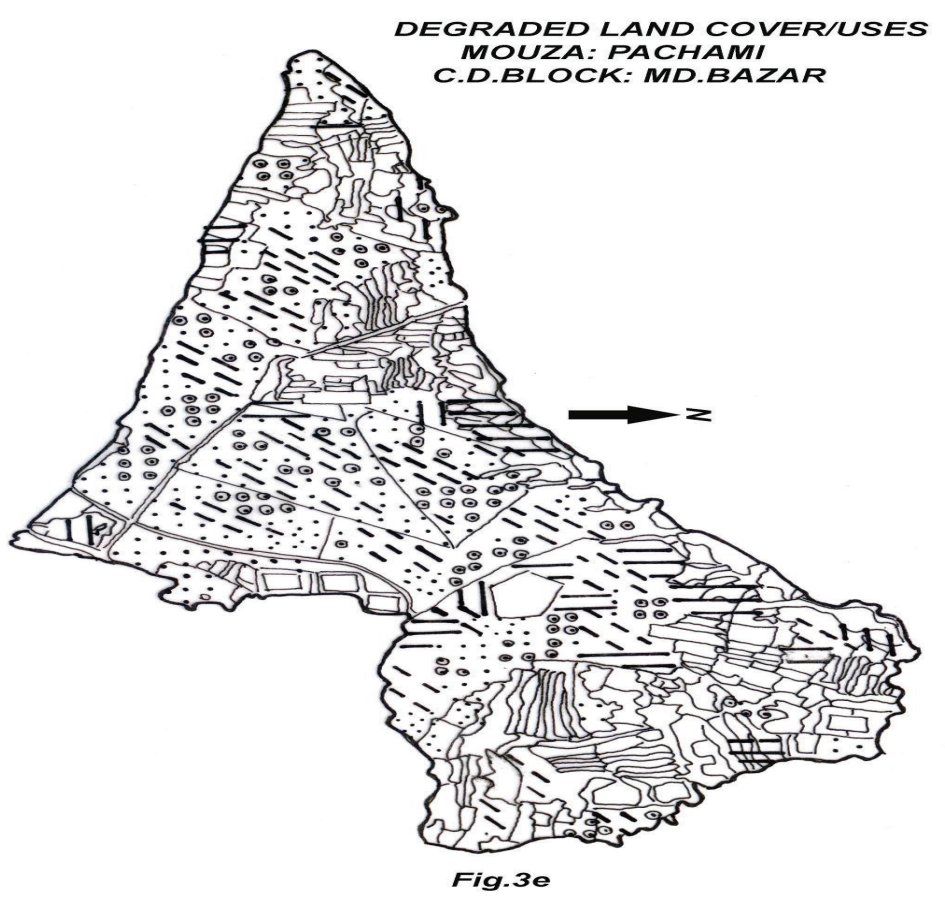

Soc. \& Nat., Uberlândia, ano 23 n. 3, 545-558, set/dez. 2011 
Figure 9: Area (\%) of Various Types of Degraded Lands in Lateritic Confinement of Sample Mouzas

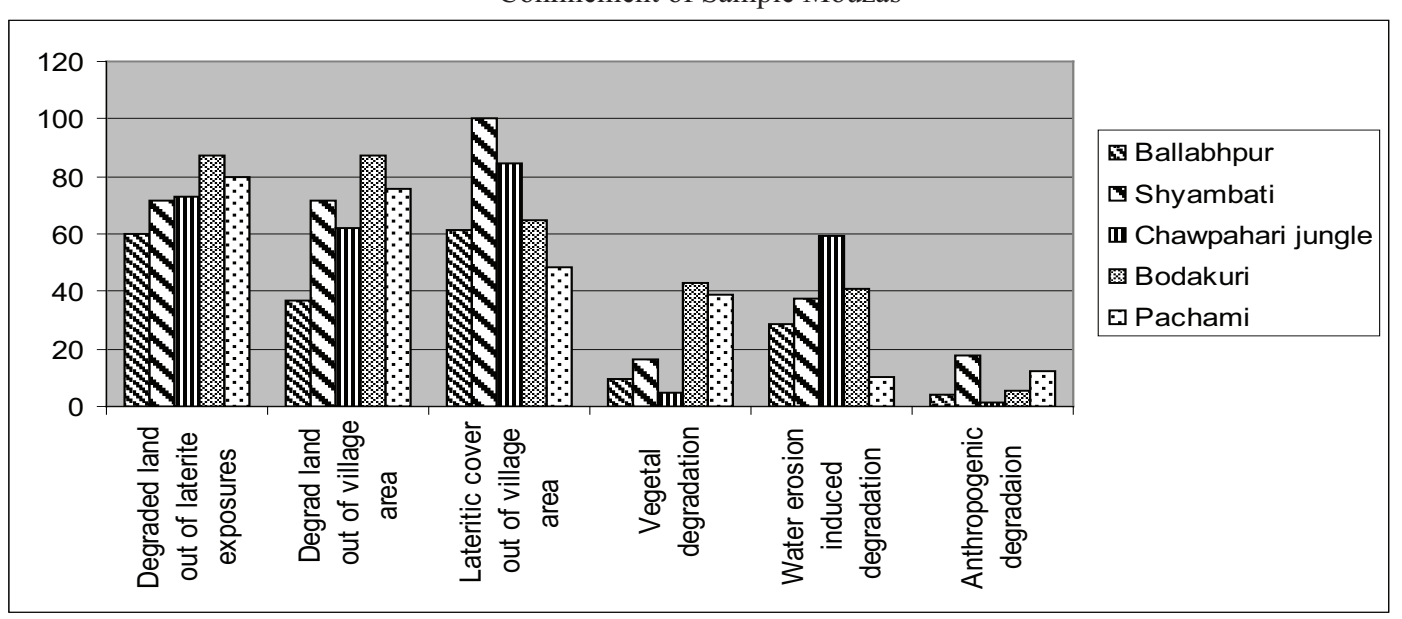

Figure 10: Fragmented Rock Particles and Soils spreaded in the agricultural Field in M. D. Bazar.

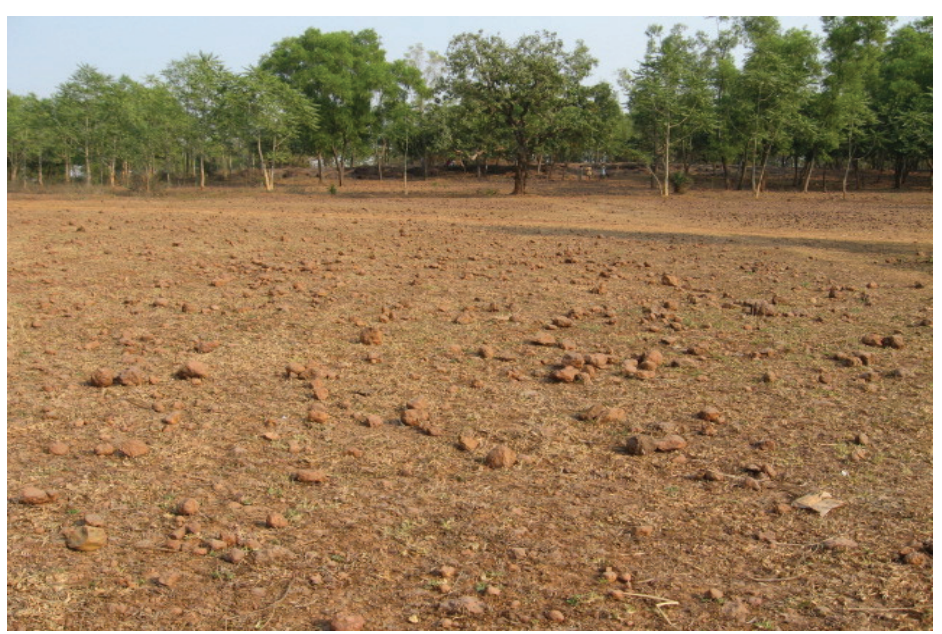

Figure 11: Area (\% out village area) under varying severity of degradation in lateritic environment.

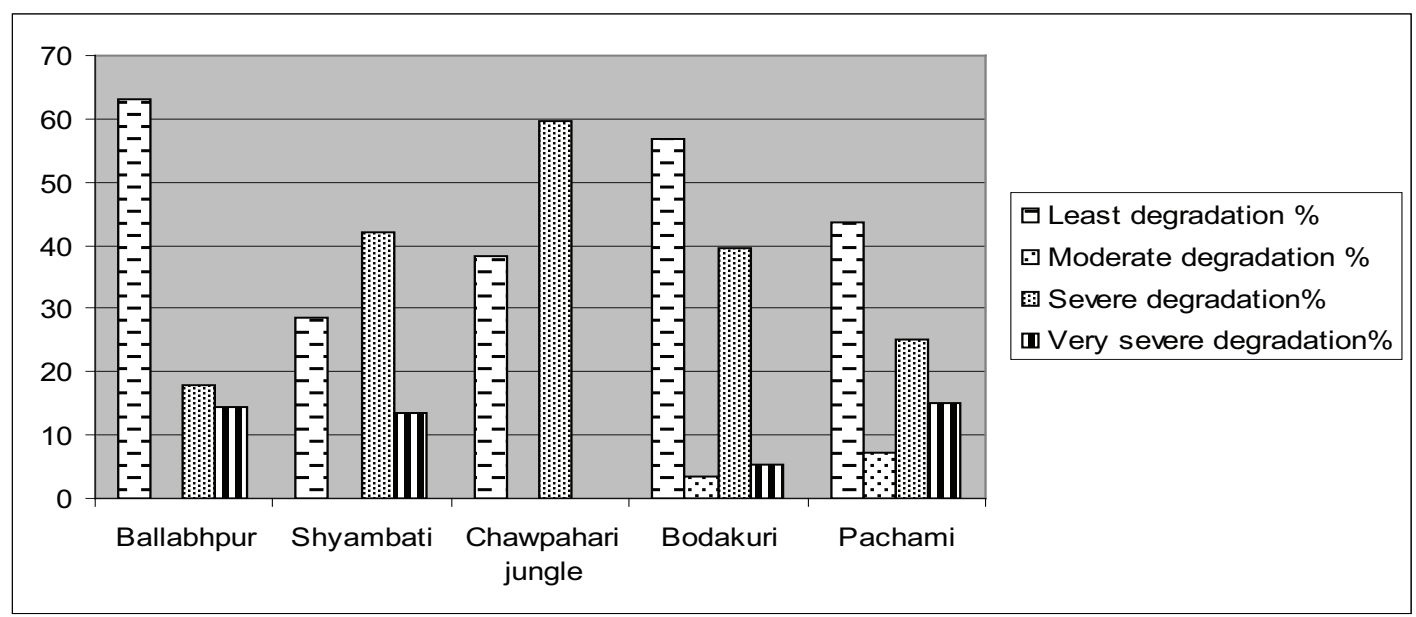

Soc. \& Nat., Uberlândia, ano 23 n. 3, 545-558, set/dez. 2011 
Bodakuri mouza in Dubrajpur C. D. Block has the highest percentage of degraded lateritic landscape $(87.31 \%$ out lateritic confinement or $56.70 \%$ out of village). This mouza reaches critical state of both inherent and anthropogenic degradation. Degraded landscape consists of agricultural land of about $13.0 \%$, social forest of $5.28 \%$, scrubland of $8.13 \%$, degraded open protected forest with sandy patch of $7.72 \%$ and with laterite nodules and boulder extraction of $8.13 \%$, sandy river bank of $8.53 \%$, sheet-rill induced barren terrain of $33.33 \%$ and barren rocky terrain of $3.25 \%$. About $76.02 \%$ of the area of the mouza Pachami is degraded including both lateritic exposures and their adjacent rocky terrain. In fact landscape of this village is mostly rocky in nature. $15.95 \%$ of agricultural land, $12.76 \%$ of social forest, $18.08 \%$ of scrubland, $4.23 \%$ of rill and sheet induced lateritic barren land, barren rocky stony terrain of $21.18 \%$ and mining waste of $16.94 \%$ undergo degradation (Table 1).

Table1: Area ( in $\mathrm{Km}^{2}$ and \% ) under Degraded Land cover/ use at cadastral level

\begin{tabular}{|c|c|c|c|c|c|}
\hline \multirow{2}{*}{$\begin{array}{l}\text { Degraded } \\
\text { cover/ Use }\end{array}$} & \multicolumn{5}{|c|}{ Sample villages } \\
\hline & Ballabhpur & Shyambati & $\begin{array}{l}\text { Chawpahari } \\
\text { Jungle }\end{array}$ & Bodakuri & Pachami \\
\hline & \multicolumn{5}{|c|}{ Area $\left(\mathrm{Km}^{2}\right.$ and \%out of lateritic exposures $)$} \\
\hline $\begin{array}{l}\text { 1.Agricultural land } \\
\text { (Rainfed mostly and } \\
\text { also irrigated) }\end{array}$ & $\begin{array}{l}0.26 \\
7.26 \%\end{array}$ & $\begin{array}{l}0.18 \\
16.7 \%\end{array}$ & $\begin{array}{l}0.21 \\
1.42 \%\end{array}$ & $\begin{array}{l}0.32 \\
13.0 \%\end{array}$ & $\begin{array}{l}0.15 \\
15.95 \%\end{array}$ \\
\hline $\begin{array}{l}\text { 2.Rill-gullied terrain } \\
\text { (Under RF) }\end{array}$ & $\begin{array}{l}0.85 \\
23.74 \%\end{array}$ & $\begin{array}{l}0.15 \\
13.39 \%\end{array}$ & $9.5665 .03 \%$ & - & - \\
\hline $\begin{array}{l}\text { 3.Sheet-rill-gullied } \\
\text { Lateritic barren land }\end{array}$ & $\begin{array}{l}0.28 \\
7.82 \%\end{array}$ & $\begin{array}{l}0.19 \\
16.96 \%\end{array}$ & $\begin{array}{l}0.30 \\
2.04 \%\end{array}$ & $\begin{array}{l}0.82 \\
33.33 \%\end{array}$ & $\begin{array}{l}0.05 \\
4.23\end{array}$ \\
\hline 4.Social Forest & - & - & - & $\begin{array}{l}0.13 \\
5.28 \%\end{array}$ & $\begin{array}{l}0.12 \\
12.76 \%\end{array}$ \\
\hline $\begin{array}{l}\text { 5.Reserve or } \\
\text { Protected Forest }\end{array}$ & $\begin{array}{l}0.19 \\
5.30 \%\end{array}$ & $\begin{array}{l}0.08 \\
7.14 \%\end{array}$ & $\begin{array}{l}0.32 \\
2.17 \%\end{array}$ & $\begin{array}{l}0.19 \\
7.72 \%\end{array}$ & - \\
\hline $\begin{array}{l}\text { 6.Open and } \\
\text { unclassified Forest } \\
\text { having extraction of } \\
\text { lateritic nodules }\end{array}$ & - & - & - & $\begin{array}{l}0.20 \\
(8.13 \%)\end{array}$ & - \\
\hline 7.Scrubland & $\begin{array}{l}0.10 \\
2.79 \%\end{array}$ & - & $\begin{array}{l}0.16 \\
1.08 \%\end{array}$ & $\begin{array}{l}0.20 \\
8.13 \%\end{array}$ & $\begin{array}{l}0.17 \\
18.08 \%\end{array}$ \\
\hline 8.Sandy river bank & $\begin{array}{l}0.24 \\
6.70 \%\end{array}$ & - & - & $\begin{array}{l}0.21 \\
8.53 \%\end{array}$ & - \\
\hline $\begin{array}{l}\text { 9.Barren } \\
\text { rocky/stony/gravelly } \\
\text { terrain }\end{array}$ & - & - & - & $\begin{array}{l}0.08 \\
3.25 \%\end{array}$ & $\begin{array}{l}0.25 \\
21.18 \%\end{array}$ \\
\hline $\begin{array}{l}\text { 10.Mining waste- } \\
\text { Basalt }\end{array}$ & - & - & - & - & $\begin{array}{l}0.20 \\
16.94\end{array}$ \\
\hline $\begin{array}{l}\text { 11.Settlment on rill- } \\
\text { gullied badland } \\
\text { /forest }\end{array}$ & $\begin{array}{l}0.24 \\
6.70 \%\end{array}$ & $\begin{array}{l}0.20 \\
17.85 \%\end{array}$ & $\begin{array}{l}0.18 \\
1.22 \%\end{array}$ & - & - \\
\hline $\begin{array}{l}\text { Total degraded land } \\
\text { in } \mathrm{Km}^{2} \& \% \text { (Out of } \\
\text { laterite exposures) }\end{array}$ & $\begin{array}{l}2.16 \\
60.33 \%\end{array}$ & $\begin{array}{l}0.80 \\
71.42 \%\end{array}$ & $\begin{array}{l}10.73 \\
72.99 \%\end{array}$ & $\begin{array}{l}2.15 \\
87.31 \%\end{array}$ & $\begin{array}{l}0.94 \\
79.66 \%\end{array}$ \\
\hline
\end{tabular}


The above statistics of 11 types of degraded land uses/covers of varying extent and severity indicate significant occurrence of inherent and anthropogenic soil or land degradation in lateritic environment. Their characteristics are as follows: Water erosion (rills, gullies and sheet) is the major geomorphic constraint in the lateritic enclosure as profound in all mouzas. Worst impact of gullying is remarkable in intensely deformed lateritic badland in Ballabhpur reserve forest which have higher annual rainfall $(1525.29 \mathrm{~mm})$, strong top soil loss (30.72 t/ha), moderately fine well developed rills and gullies $\left(3.08 / \mathrm{m}^{2}\right)$ and severe $(1.05$ $\mathrm{km}^{2}$ or $17.97 \%$ of mouza ) - very severe $\left(0.85 \mathrm{~km}^{2}\right.$ or $14.55 \%$ of mouza) degradation status .As a result, pisolite-pebble-gravel assorted laterite horizon has been badly exposed in Ballabhpur.

On the contrary, Chawpahari jungle belonging to the higher rainfall regime $(1527.0 \mathrm{~mm})$ being dominated by forest landscape does not display well developed gullies (frequency of rills \& gullies 2.12/ $\mathrm{m}^{2}$ ) and relief deformations and badland formation in spite of having largest laterite exposure and the higher top soil loss (27.14 t/ha). $10.34 \mathrm{~km}^{2}$ or $59.49 \%$ of its village area is subjected to rill-gully erosion. Shyambati lies entirely on the badly deformed badland. Bodakuri mouzas being devoid of significant gullies still have widespread of rill and sheet erosion induced lateritic barren and scrub land $\left(1.55 \mathrm{~km}^{2}\right.$ or $40.89 \%$ of village , mean annual soil loss: $29.82 \mathrm{t} / \mathrm{ha}$, drainage frequency:2.07/ $\mathrm{m}^{2}$ ) though. Figure 12 .

Table 2 shows the Area $\left(\mathrm{Km}^{2} \& \%\right)$ affected by varying severity of degradation and pedo-geomorphic constraints in terms of average annual top soil loss (TSL), relief deformations (TD) and type of degrading land-uses in lateritic enclosures at cadastral level in the sample Mauza/Villages.

Figure 12: Average annual soil loss (t/ha), Drainage frequency $/ \mathrm{m}^{2}$ and density $\mathrm{m} / \mathrm{m}^{2}$.

(including rills and gullies in severely degraded land)

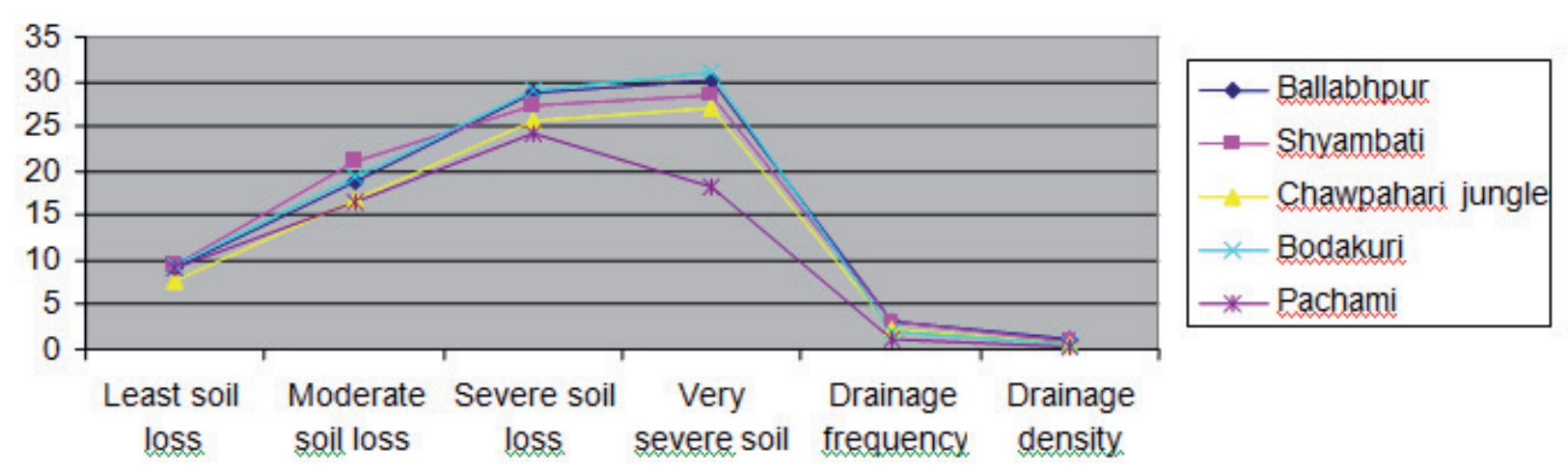


Table 2: Severity of Degradation in Sample Mouza/Villages

\begin{tabular}{|c|c|c|c|c|c|c|c|}
\hline \multirow{3}{*}{$\begin{array}{l}\text { Severity of } \\
\text { degradation }\end{array}$} & \multirow{3}{*}{$\begin{array}{l}\text { Terrain with } \\
\text { pedo- } \\
\text { geomorphic } \\
\text { constraints }\end{array}$} & \multicolumn{6}{|c|}{ Sample Mouza / Villages } \\
\hline & & $\begin{array}{l}\text { Ballabhp } \\
\text { ur }\end{array}$ & $\begin{array}{c}\text { Shyamb } \\
\text { ati }\end{array}$ & $\begin{array}{c}\text { Chawpaha } \\
\text { ri } \\
\text { Jungle }\end{array}$ & $\begin{array}{l}\text { Bodaku } \\
\text { ri }\end{array}$ & $\underset{\text { i }}{\text { Pacham }}$ & $\begin{array}{l}\text { Affected land cover/uses } \\
\text { and soil loss t/ha }\end{array}$ \\
\hline & & \multicolumn{6}{|c|}{ Area in $\mathrm{Km}^{2}$ and \% out of the total village area } \\
\hline Least & $\begin{array}{l}\text { Least mean } \\
\text { annual topsoil } \\
\text { loss (TSL } \\
(<10.0 t / h a) \text { and } \\
\text { terrain } \\
\text { deformations(T } \\
\text { D) }\end{array}$ & $\begin{array}{l}3.68 \\
63.04 \%\end{array}$ & $\begin{array}{l}0.32 \\
28.58 \%\end{array}$ & $\begin{array}{l}6.65 \\
38.27 \%\end{array}$ & $\begin{array}{l}1.64 \\
56.70 \%\end{array}$ & $\begin{array}{l}0.73 \\
43.71 \%\end{array}$ & $\begin{array}{l}\text { terrain without distinct } \\
\text { lateritic exposures }\end{array}$ \\
\hline Moderate & $\begin{array}{l}\text { Moderate or } \\
\text { moderately } \\
\text { high TSL } \\
(10.0-25.0 \mathrm{t} / \mathrm{ha}) \\
\text { and least/ } \\
\text { moderate TD }\end{array}$ & $\begin{array}{l}0.26 \\
4.45 \%\end{array}$ & $\begin{array}{l}0.18 \\
16.07 \%\end{array}$ & $\begin{array}{l}0.39 \\
2.24 \%\end{array}$ & $\begin{array}{l}0.45 \\
11.87 \%\end{array}$ & $\begin{array}{l}0.27 \\
16.16 \%\end{array}$ & $\begin{array}{l}\text { Rainfed and irrigated } \\
\text { marginal } \\
\text { agricultural } \\
\text { \& social forest }\end{array}$ \\
\hline Severe & $\begin{array}{l}\text { Severe / least } \\
(25-29 t / \text { ha or } \\
\text { least where } \\
\text { sandy TSLand } \\
\text { least /moderate } \\
\text { \&moderately } \\
\text { high } \\
\text { TD }\end{array}$ & $\begin{array}{l}1.05 \\
17.97\end{array}$ & $\begin{array}{l}0.47 \\
41.96\end{array}$ & $\begin{array}{l}10.34 \\
59.49\end{array}$ & $\begin{array}{l}1.5 \\
39.57\end{array}$ & $\begin{array}{l}0.42 \\
25.14 \%\end{array}$ & $\begin{array}{l}\text { Lateritic barren and bad } \\
\text { land adjacent to } \\
\text { irrigation canal \& } \\
\text { Settlement in badland or } \\
\text { in reserve/ } \\
\text { protected lopen forest, } \\
\text { Scrub } \\
\text { land, Sandy patch, } \\
\text { mining of lateritic waste }\end{array}$ \\
\hline Very severe & $\begin{array}{l}\text { Very Severe } \\
\text { TSL }>29 \text { t/ha) } \\
\text { and strong } \\
\text { terrain } \\
\text { deformations } \\
\text { TD } \\
\end{array}$ & $\begin{array}{l}0.85 \\
14.55 \%\end{array}$ & $\begin{array}{l}0.15 \\
13.39 \%\end{array}$ & - & $\begin{array}{l}0.20 \\
5.27 \%\end{array}$ & $\begin{array}{l}0.25 \\
14.97 \%\end{array}$ & $\begin{array}{l}\text { Intensely rill/ gully/sheet } \\
\text { erosion induced Lateritic } \\
\text { barren and badland } \\
\text { (though forested), } \\
\text { Rocky terrain and Rock } \\
\text { quarry }\end{array}$ \\
\hline \multicolumn{2}{|c|}{$\begin{array}{l}\text { Total degraded land in } \mathrm{Km}^{2} \& \\
\% \text { out of the total area of } \\
\text { Mouza }\end{array}$} & $\begin{array}{l}2.16 \\
36.98 \%\end{array}$ & $\begin{array}{l}0.8 \\
71.42 \%\end{array}$ & $\begin{array}{l}10.73 \\
61.73 \%\end{array}$ & $\begin{array}{l}2.15 \\
56.70 \%\end{array}$ & $\begin{array}{l}0.94 \\
76.02 \%\end{array}$ & \\
\hline \multicolumn{2}{|c|}{$\begin{array}{l}\text { Total lateritic exposures in } \mathrm{Km}^{2} \\
\text { \& \% out of the total } \\
\text { mouza area }\end{array}$} & $\begin{array}{l}3.58 \\
61.30 \%\end{array}$ & $\begin{array}{l}1.12 \\
100 \%\end{array}$ & $\begin{array}{l}14.70 \\
84.57 \%\end{array}$ & $\begin{array}{l}2.46 \\
64.90 \%\end{array}$ & $\begin{array}{l}1.18 \\
48.50 \%\end{array}$ & \\
\hline \multicolumn{2}{|c|}{$\begin{array}{l}\text { Total village/Mouza area in } \\
\mathrm{Km}^{2}\end{array}$} & 5.84 & 1.12 & 17.38 & 3.79 & 1.67 & \\
\hline
\end{tabular}

Recently they have been brought under forest land. Pachami mouza is least affected by rill- gully-sheet erosion as characterized by relatively less mean annual rainfall $(1400.0 \mathrm{~mm})$ least extent of lateritic coverage, dominance of rocky terrain, coarse drainage frequency $\left(0.42 / \mathrm{m}^{2}\right)$. It accounts for $0.17 \mathrm{~km}^{2}$ or $10.17 \%$ of its total area and only confined to lateritic barren (Table 3). All sample villages are subject to vegetal degradation to some extent. Such problem grows acute in Bodakuri $\left(1.62 \mathrm{~km}^{2}\right.$ or $42.74 \%$ or of village) and Pachami $\left(0.67 \mathrm{~km}^{2}\right.$ or $\left.40.11 \%\right)$ in view of forest blank by local people, illegal extractions of laterite wastes from rill-sheet induced gently sloping lateritic barren and existence of stony and rocky terrain (Plate-7). It is important to say that these two villages hold still considerable extent of barren land in this era when there is crisis for land and water. Bodakuri (5.27\% of village), Pachami (11.97\%) and Shyambati (17.85\%) mouzas undergo notable anthropogenic degradation due to radical changes in land uses on laterite exposures. Highly deformed badland topography in shyambati mouza has been 
mostly converted into residential area by obliterating old ephemeral drainage network, adversely modifying degraded soil profile of poor physical and chemical status, fresh growth of ramified new drainage network.

In the study area, lateritic exposures attain mostly undergone severe and moderate degradation status otherwise all villages are dominated by least degradation status. Severe and very severe degraded lands are particularly related to rill-gully-erosion induced badland in reserve forest or moderate relief deformity in protected forest; barren lateritic or rocky terrain with least and moderate deformity and mining sites. Severe and very severe degradation prevail in

Table 3: Area $\left(\mathrm{km}^{2}\right.$ and \% out of village area) affected by various types of degradation and pedo- geomorphic constrain based Priority for action plan
$1.9 \mathrm{Km}^{2}$ or $32.53 \%$ in Ballabhpur mouza, $0.62 \mathrm{Km}^{2}$ or 55.35 in Shyambati, $10.34 \mathrm{~km}^{2}$ in $59.49 \%$ in Chawpahari jungle, $1.70 \mathrm{~km}^{2}$ or $44.84 \%$ in Bodakuri, $0.67 \mathrm{~km}^{2}$ or $40.11 \%$ (out of its total village area) in Pachami village. Agricultural land and social forest confront with moderate degradation status having moderate or moderately high terrain deformity as noted in sample villages.

\begin{tabular}{|c|c|c|c|c|c|}
\hline $\begin{array}{l}\text { Villages or } \\
\text { Mouza }\end{array}$ & $\begin{array}{l}\text { Area affected } \\
\text { by Severe- } \\
\text { Very severe } \\
\text { degradation } \\
\text { and land use }\end{array}$ & $\begin{array}{c}\text { Area } \\
\text { affected by } \\
\text { vegetal } \\
\text { degradation }\end{array}$ & $\begin{array}{l}\text { Area affected } \\
\text { by intense } \\
\text { water erosion } \\
\text { induced } \\
\text { degradation }\end{array}$ & $\begin{array}{l}\text { Area affected by } \\
\text { anthropogenic } \\
\text { degradation }\end{array}$ & $\begin{array}{c}\text { Pedo- } \\
\text { geomorphic } \\
\text { Priority for } \\
\text { conservatio } \\
\text { n action }\end{array}$ \\
\hline Ballabhpur & $\begin{array}{l}1.9 \mathrm{~km}^{2} \text { or } \\
32.53 \%\end{array}$ & $\begin{array}{ll}0.57 \mathrm{k} & \mathrm{m}^{2} \text { or } \\
9.76 \% & \end{array}$ & $\begin{array}{ll}1.66 \mathrm{k} & \mathrm{m}^{2} \text { or } \\
28.42 \% & \end{array}$ & $\begin{array}{l}0.24 \mathrm{k} \mathrm{m}^{2} \text { or } 4.10 \\
\%\end{array}$ & High \\
\hline Shyambati & $\begin{array}{l}0.62 \mathrm{k} \mathrm{m}^{2} \text { or } \\
55.35 \%\end{array}$ & $\begin{array}{l}1.12 \mathrm{k} \mathrm{m}^{2} \text { or } \\
16.07 \%\end{array}$ & $\begin{array}{ll}0.42 \mathrm{k} & \mathrm{m}^{2} \text { or } \\
37.50 \% & \end{array}$ & $\begin{array}{l}0.20 \mathrm{k} \mathrm{m}^{2} \text { or } 17.85 \\
\%\end{array}$ & High \\
\hline $\begin{array}{c}\text { Chawpahari } \\
\text { Jungle }\end{array}$ & $\begin{array}{l}10.34 \mathrm{k} \mathrm{m} \mathrm{m}^{2} \text { or } \\
59.49 \%\end{array}$ & $\begin{array}{l}0.78 \mathrm{k} \quad \mathrm{m}^{2} \text { or } \\
4.48 \%\end{array}$ & $\begin{array}{ll}10.34 \mathrm{k} & \mathrm{m}^{2} \text { or } \\
59.49 \% & \end{array}$ & $\begin{array}{l}0.18 \mathrm{k} \mathrm{m}^{2} \text { or } 1.03 \\
\%\end{array}$ & Moderate \\
\hline Bodakuri & $\begin{array}{l}1.70 \mathrm{k} \mathrm{m}^{2} \text { or } \\
44.84 \%\end{array}$ & $\begin{array}{ll}1.62 \mathrm{k} & \mathrm{m}^{2} \text { or } \\
42.74 \% & \end{array}$ & $\begin{array}{l}1.55 \mathrm{k} \quad \mathrm{m}^{2} \text { or } \\
40.8 \%\end{array}$ & $\begin{array}{l}0.20 \mathrm{k} \mathrm{m}^{2} \text { or } 5.27 \\
\%\end{array}$ & Very high \\
\hline Pachami & $\begin{array}{ll}0.67 \mathrm{k} & \mathrm{m}^{2} \text { or } \\
40.11 \% & \\
\end{array}$ & $\begin{array}{ll}0.65 \mathrm{k} & \mathrm{m}^{2} \text { or } \\
38.92 \% & \end{array}$ & $\begin{array}{ll}0.17 \mathrm{k} & \mathrm{m}^{2} \text { or } \\
10.17 \% & \\
\end{array}$ & $\begin{array}{l}0.20 \mathrm{k} \mathrm{m}^{2} \text { or } 11.97 \\
\%\end{array}$ & Very high \\
\hline
\end{tabular}

Hence, it is clear that all villages witness physical and chemical pedo-geomorphic deterioration currently as reflected in soil profiles and land cover/ use in their lateritic confinement.

\section{Pedo-geomorphic constraints based priority and Action Plan:}

First priority (very high) has been given to Bodakuri and Pachami villages as they have higher inherent and anthropogenic severity, more types and larger extent of degraded land uses in lateritic exposures and their vicinity. Second priority (high) is given to Ballabhpur and Shyambati mouzas inspite of typical lateritic badland with highest magnitude of annual top soil loss, physical and chemical deterioration due to intense gulling and intensely erodible leached lateritic soil profile. In these two mouzas, types and over all extent of degraded lands are relatively small and mostly reclaimed by Ballabhpur sanctuary - reserve forest and settlement. But there is still persistence of higher erodibilty as evidenced by the higher topsoil loss, ramified rills and gullies and forest blank/forest tree felling (government policy) (Table 3). Chawpahari Jungle mouza gets third priority (Moderate) though it has largest lateritic exposures and widespread area 
affected by severe water erosion. But it is characterized by moderate or least rill-gully infested relief deformity and low percentage of vegetal and anthropogenic degradation.

\section{CONCLUSION}

So the above analysis makes it clear that degradation of existing lateritic soilscape can be considered as irresistible. All villages have significant extent of degraded laterites otherwise villages are dominated by least severity of degradation. Inherently poor physical and chemical status of existing lateritic soil profile and radical conversion of land uses are the key factors of such degradation. Inherent and anthropogenic pedo-geomorphic constraints related to acidity; water erosion, sand splay, barrenness, removal of top soil horizon in Bodakuri and Pachami villages; remarkable modification of badland soil profile in Shayambati mouza hinder its environmental recovery. Lateritic exposures in these mouzas are suffering from moderate to very severe degradation. In fact, quite a number of conservation practices have been undertaken by the government and local people. But there is a substantial gap. The higher prioritization for pedo-geomorphic conservation actions has given to four villages to make friendly lateritic landscape in accordance with cost effective site suitability.

According to this assessment at cadastral level the following action plans for conservation of lateritic environment and its surrounding can be suggested: Three major approaches like vegetative, engineering and a combination of both may be employed in villages of $1^{\text {st }}$ and $2^{\text {nd }}$ priority to control water erosion to consolidate unstable slope and to stabilize gully heads and bed. Stabilization of gullies can be done by more traditional a forestation, reforestation, plantation forest, grass rip rap inter planted with cutting -earth plug, brush fills and check dam which act as settling ponds where eroded soil particles are deposited and ultimately enhance further growth of natural and planted vegetation. More effort should be given to create social, agro forestry, reforestation, plantation forest to reduce extent of barrenness in villages of $1^{\text {st }}$ priority. Immediate plantation in forest blank and on barren lateritic lands (affected by rill and sheet erosion) which are recently brought under forest land. But forest generation is not yet started as noted in villages of $1^{\text {st }}$ priority. Silvi pasture may be suitable for this type of terrain. In village of $3^{\text {rd }}$ priority like Chawpahari jungle, forest plantation is needed specially in sandy patches and also in forest blank. In degraded fragmented rain-fed arable land in the lateritic territory, Kharif rice /Rabi vegetable /oil seeds can be cultivated with the help of integrated nutrient management, lime, constructing dug well and tree plantation around plots.

\section{REFERENCES}

AJAI et al. Desertification And Land Degradation Status Mapping in India. Current Science. v. 97, n. 10; 25, p. 1478-1483, nov. 1990.

BANERJEE, P. K. Basic Research On Laterites in Tropical Countries. Quaternary International, Revitalization concepts in Paleopedology. V. 51-52, 1998. P. $69-72$.

BISWAS, A. Laterites And Lateritoids Of Rarh Bengal. In: DATYE, V. S. et al. (Ed.). Explorations in The Tropics. Prof. K. D. Dikshit Felicitation Volume Committee, 1987.

BRAIMOH ADEMOLA K. et al. Land Use and Soil Resources. ISBN, 2008.

CLIFF, D. et al. The high Deccan duricrusts of india and their significance for the laterite issue, Journal of Earth Science. Springer India in Co Publication With Indian Academy of science. v. 117, n. 5, oct. 2008.

DABRAL. P. P. et al. Soil erosion Assessment in Hilly Catchment of North East India using USLE, GIS and Remote Sensing. Water Resources Management. v. 22, n. 12, p. 1783-1798. dec. 2008. 
GRAU, H. R. et al. Globalization and land-use transition in Latin America ecology and society. Ecology and society. v. 13, n. 2, 2008.

JHA, V. C.; KAPAT, S. Rill and gully erosion risk of laterite terrain in south western Birbhum district, West Bengal, India, Sociedade \& Natureza, Uberlândia, v. 21 n. 2, p.141-158, 2009.

JHA, V. C. Denudational processes and landform characteristics in the laterites of Birbhum district. Transactions of the Institute of Indian Geographers, Dept of Geography. West Bengal, India, Pune, p.1929, 2005.

MCFARLANE, M. J. Geomorphological analysis of laterites and its role in prospecting geological survey of India. Memoirs. Laterization Processes. v. 120, 1986. p. 41-50.

PACARDO, P. E. Soil erosion Soil erosion management: Proceedings of a Workshope held at PCARRD, Philippines. 1984. p. 82-85.

PRESCOTT, J. A. The Early History Of The Use Of term Laterite. European. Journal Of Soil Science, v. 5, 1 ed. 2006, p.1-6.

ROYCHOWDHURY, M. K. et al. Recent concepts on the origin of Indian laterites. Proc. Nat. Inst. Sci. India. v. 31 (A): 547-558. Amsterdam, 1965, p. 226.

SANTHANAM, A. K. et al. Investigation of laterite stones for building purpose from malabar region, kerala state SW India - Part 1: field studies and profile characterization. Construction and Building Materials. v. 21, 1 ed. p. 73-82, jan. 2007.
SEHGAL, J. et al. Red and lateritic soil, managing red and lateritic soils for sustainable agriculture. $\mathrm{v}$. 1, 1998. p. 57-75.

SING, S.; DUBEY. A. Gully erosion and management, methods and applications (A field Mannual). New Academic Publishers. Delhi. 2002, p. 229-237

THOMAS, P. K. Genesis of Barren Laterite capped plateau in the west coast and then possible utilization. In: Proc. Int. Seminar on laterization process. Trivandram. Rotterdam. 1981. p. 436-439.

VALENTIN, C. et al. Gully Erosion: Impacts, Factors and Control. Catena. v. 63, 2; 3 ed. p. 132-153, oct. 2005.

VOLKOFF, B. Iron Concretion Of the Latosolic Cover in Northeast Brazil. In: MELFI, A. J.; CARVALHO, A. (Ed.). Laterization processes, proceedings of II international seminar on laterization processes. USP. São Paulo. Brazil. 4 - 12 jul. 1982, p. 527-540.

WISCHMEIR; SMITH. Available in: http://www.fao. org/docrep/T1765E/t1765e0e.htm. Accessed: dec. 2010.

ZHANG, Y. et al. Integration of modified USLE into GIS framework to assess soil erosion risk, land degradation and development. v. 20, 1 ed. 2008. p. 84-91. 